TARNOWSKIE STUDIA TEOLOGICZNE 36 (2017) NR 2, S. 141-158

http://dx.doi.org/10.15633/tst.2620

Kamil Trombik ${ }^{1}$

UNIWERSYTET PAPIESKI JANA PAWŁA II W KRAKOWIE

\title{
Aleksandra Usowicza wkład do badań nad dziejami filozofii krakowskiej
}

Niewiele uwagi jak dotąd poświęcono analizie prac historyczno-filozoficznych ks. Aleksandra Usowicza (1911-2002), zwłaszcza tej części jego spuścizny pisarskiej, w której podjął się badań nad krakowską myślą filozoficzną ${ }^{2}$. Jest o tyle zaskakujące, że teksty Usowicza z zakresu filozofii polskiej tworzą istotną część jego dorobku naukowego. Z drugiej jednak strony trzeba otwarcie przyznać, iż Usowicz prowadził swoje badania na tym gruncie przez krótki okres, nie licząc opracowań jego autorstwa poświęconych osobie ks. Konstantego Michalskiego, znaczącego w xx wieku polskiego historyka filozofii. Wychodząc jednak z założenia, że myśl Usowicza domaga się dalszych, pogłębionych studiów, autor niniejszego artykułu postanowił przyjrzeć się, w jaki sposób uczony ten postrzegał filozofię krakowskiego środowiska naukowego, rozwijaną w dwóch okresach: a) między xv a XVII wiekiem, b) u schyłku xıx i w pierwszej połowie $\mathrm{xx}$ wieku. Starając się zatem dołożyć cegiełkę pod budowę przyszłych opracowań myśli filozoficznej Usowicza (które - miejmy nadzieję - nadal będą powstawały), podjęto w tym artykule próbę uzasadnienia tezy o znaczącej roli jego pism dla zrozumienia dziejów krakowskiej filozofii, szczególnie tej uprawianej w duchu tomistycznym.

1 Kamil Trombik - doktorant na Wydziale Filozoficznym Uniwersytetu Papieskiego Jana Pawła II w Krakowie. Realizuje program badawczy „Filozofia na Papieskiej Akademii Teologicznej w Krakowie. Studium historyczno-analityczne obejmujące lata 1976-1991". Zainteresowania: historia filozofii polskiej, filozofia przyrody.

2 Autor uzyskał środki finansowe na przygotowanie rozprawy doktorskiej z Własnego Funduszu Stypendialnego Uniwersytetu Papieskiego Jana Pawła II w Krakowie. 


\section{Sylwetka filozofa}

Pobieżny rzut oka na bibliografię prac Usowicza, odsłania szeroką panoramę problemów, z jakimi w czasie swojej ścieżki naukowej zmagał się krakowski filozof, związany przede wszystkim z Wydziałem Teologicznym Uniwersytetu Jagiellońskiego, Papieską Akademią Teologiczną oraz Instytutem Teologicznym Księży Misjonarzy. Główny ton spuściźnie pisarskiej Usowicza nadają niewątpliwie zagadnienia, które należałoby umieścić w kontekście teorii bytu, psychologii racjonalnej i filozofii społecznej. Krakowski myśliciel, w zgodzie z duchem myśli tomistycznej, dostrzegał jednak związki między różnymi dziedzinami filozofii, a także między filozofią a szeroko rozumianą kulturą współczesną. $\mathrm{Z}$ tego względu skłaniał się ku bardzo wszechstronnym badaniom, poruszając nawet problemy przypisywane tradycyjnie etyce, antropologii filozoficznej czy logice. Od tej ostatniej zaczynał zresztą swoją ścieżkę naukową, broniąc na Angelicum w Rzymie rozprawę doktorską o teorii definicji w dziełach Arystotelesa. Promotorem owej pracy był znany w polskim środowisku logik, o. Józef Bocheński op. Po powrocie do Krakowa, w którym przebywał wcześniej w latach 1927-1934, Usowicz kontynuował przerwaną współpracę z innym znanym i cenionym - zwłaszcza na gruncie mediewistyki - myślicielem tamtego okresu, Konstantym Michalskim cm. Relacja mistrz-uczeń cechowała wzajemny stosunek obu myślicieli aż do nagłej śmierci Michalskiego w 1947 roku. Usowicz pozostał jednak pod wpływem swojego nauczyciela nawet po wielu latach, do końca swojego życia kontynuując pracę edytorską i kompilatorską prac Michalskiego, publikując przy różnych okazjach szereg artykułów na temat twórczości zasłużonego historyka filozofii średniowiecznej.

Przebieg ścieżki naukowej Usowicza związany był początkowo z Wydziałem Teologicznym Uniwersytetu Jagiellońskiego w Krakowie. Tutaj współpracował z Michalskim, tutaj także zdobywał kolejne stopnie naukowe (doktorat $\mathrm{z}$ teologii, habilitacja $\mathrm{z}$ filozofii), a po śmierci swego nauczyciela objął kierownictwo Katedry Filozofii Chrześcijańskiej. Wraz z likwidacją Wydziału Teologicznego z Uniwersytetu Jagiellońskiego w 1954 roku nie przeniósł się - pomimo zaistniałej możliwości - do nowo powstałej Akademii Teologii Katolickiej w Warszawie, zadowalając się prowadzeniem skromniejszej działalności naukowo-dydaktycznej w licznych seminariach duchownych w Polsce. W miejscu tym warto również zwrócić uwagę na wkład Usowicza w powstanie Papieskiej Akademii Teologicznej w Krakowie, bezpośredniej 
spadkobierczyni Wydziału Teologicznego UJ, który po roku 1954 nadal prowadził działalność jako instytucja kościelna pod nazwą Papieski Wydział Teologiczny (do czasu powołania Papieskiej Akademii Teologicznej w roku 1981). To właśnie w krakowskim środowisku PAT Usowicz prowadził szereg zajęć oraz kierował Katedrą Historii Filozofii - i to już od momentu jej powstania w ramach tzw. Sekcji Filozofii Wydziału Teologicznego, którą ustanowiono w 1970 roku. Wreszcie na Papieskiej Akademii Teologicznej Usowicz uzyskał tytuł profesora zwyczajnego (1986) i przeszedł na emeryturę (1990). Bardziej szczegółowe wątki biograficzne, związane z niewątpliwie barwną i ciekawą postacią Usowicza, można znaleźć w kilku opracowaniach, które opublikowano na przestrzeni ostatnich lat ${ }^{3}$.

\section{Badania nad krakowską myślą scholastyczną - zakres czasowy i tematyczny}

Napomknięto wyżej o rozległości badań prowadzonych przez Usowicza na gruncie filozofii. Komentatorzy dzieł krakowskiego myśliciela zwracają przede wszystkim uwagę na bogactwo opracowań Usowicza z zakresu filozofii systematycznej. Niewiele jednak wspomina się o jego działalności jako historyka filozofii, zwłaszcza filozofii polskiej ${ }^{4}$. Nie znaczy to oczywiście, że nie można wysunąć tezy o wkładzie Usowicza do badań nad dziejami rodzimej filozofii. Już jako komentator i kompilator prac Michalskiego zasługiwałby na uwagę historyków polskiej myśli filozoficznej xx wieku. W tym artykule zwrócę uwagę także na to, iż jego wysiłki w zakresie polskiej filozofii nie ograniczały się tylko do badań nad spuścizną swojego nauczyciela, lecz obejmowały również znaczące prace z dziejów krakowskiej myśli filozoficznej.

Trzeba jednak od razu zaznaczyć, że ilość prac historyczno-filozoficznych Usowicza jest niewielka w stosunku do dorobku naukowego jego nauczyciela. Podobnie rzecz ma się z recepcją pism, które Usowicz pozostawił po sobie. Znacznie mniejsze zainteresowanie opracowaniami „ucznia” nie przesądza jednak w żaden sposób o ich niższej wartości. W pracy tej bronił będę tezy,

\footnotetext{
3 Odsyłam zwłaszcza do: M. Markowski, Aleksander Usowicz - wielki uczony i dobry nauczyciel przełomowych czasów, „Informator Instytutu Teologicznego Księży Misjonarzy” 2002 nr 22, s. 25-77.

4 Zob. T. Pawlikowski, Filozofia teoretyczna ks. Aleksandra Usowicza, Kraków 2009.
} 
iż wkład Usowicza w badania nad krakowską myślą filozoficzną (zwłaszcza w wydaniu tomistycznym) jest godny szerszego odnotowania, co więcej zasługuje na większą uwagę historyków filozofii polskiej5.

Pierwsze, co rzuca się w oczy podczas opracowywania dzieł Usowicza z zakresu filozofii krakowskiej, to nie tylko ich tematyka, ale także okres publikowania. Ksiądz Usowicz zasadniczo problematykę filozofii polskiej podejmuje tuż po zakończeniu drugiej wojny światowej, w kilku artykułach publikowanych w latach 1946-1949, a więc w początkowym okresie samodzielnej pracy naukowej na Uniwersytecie Jagiellońskim. Przecierając szlaki dla powojennych badań z zakresu filozofii polskiej, publikuje prace historyczne związane z takimi postaciami, jak Jan z Głogowa (1445-1507), Stanisław Sokołowski (1536-1593), Stanisław Wieczorkowski (zm. 1657), Franciszek Gabryl (1866-1914) i Jacek Woroniecki (1878-1949). Wyjątkowo płodny okres powojenny nie jest jednak kontynuowany na podobną skalę w latach późniejszych, co być może miało związek ze śmiercią Michalskiego i przejęciem wielu obowiązków po mistrzu, a w dalszej perspektywie także likwidacją Wydziału Teologicznego Uniwersytetu Jagiellońskiego, utratą etatu na tejże uczelni i - co za tym idzie - dostępu do źródeł Biblioteki Jagiellońskiej. Z drugiej strony należy podkreślić zasługi Usowicza na gruncie filozofii polskiej, wykonał bowiem ogromną pracę przy opracowywaniu i wydawaniu dorobku Michalskiego, którego przecież śmiało można umieścić w gronie najwybitniejszych tomistów polskich (a przy okazji również pośród najważniejszych rodzimych filozofów pierwszej połowy $\mathrm{xx}$ wieku, oddziałujących także poza granicami naszego kraju). Warto w tym miejscu wspomnieć jeszcze o drobnym epizodzie, związanym z publikacją dziewiątego tomu Polskiego słownika biograficznego, gdzie Usowicz we współpracy z Leszkiem Hajdukiewiczem przygotował biogram XVI-wiecznego myśliciela krakowskiego, Grzegorza ze Stawiszyna, rektora Akademii Krakowskiej i ważnego przedstawiciela nominalizmu w Polsce. Jak widać, badania historyczno-filozoficzne w przypadku Usowicza nie ograniczają się wyłącznie do kilku artykułów powojennych, lecz obejmują również znaczące prace publikowane w okresie późniejszym, mimo że skupiają się one wówczas

5 Brak odwołania do osoby ks. Usowicza między innymi w: J. Skoczyński, J. Woleński, Historia filozofii polskiej, Kraków 2010; W. Wąsik, Historia filozofii polskiej, t. 1: Scholastyka, renesans, oświecenie, Warszawa 1958. 
przede wszystkim wokół upowszechniania dorobku naukowego jednego filozofa - Konstantego Michalskiego.

\section{Pojedyncze opracowania z dziejów krakowskiej filozofii scholastycznej}

Za pierwszą chronologicznie pracę, w której Usowicz dzieli się wynikami badań z zakresu krakowskiej myśli filozoficznej, należy uznać artykuł Poglady moralno-polityczne ks. Stanisława Sokołowskiego", zawarty w pierwszym

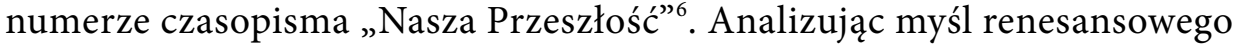
kaznodziei, cenionego w swoim czasie wykładowcy Akademii Krakowskiej, Usowicz skupił się na osadzeniu jego poglądów społecznych w kontekście filozofii Arystotelesa i św. Tomasza z Akwinu, dla których polityka jest nieodłącznie związana $\mathrm{z}$ nauką o duszy i etyką. Usowicz zwraca w swojej pracy uwagę na główne idee obecne w refleksjach Sokołowskiego, do których należą: problem upadku moralno-religijnego i politycznego narodów, wolność i jej granice w państwie oraz wady narodowe (ze szczególnym uwzględnieniem rozrzutności). Tematyka ta - na co zwraca uwagę Usowicz przesiąknięta jest u Sokołowskiego kontekstem biblijnym i filozoficznym, nawiązującym do myśli antyku (Platon, Arystoteles, Cyceron). W podsumowaniu Usowicz podkreśla, że Sokołowskiego zaliczyć należy do grona tych pisarzy politycznych, którzy nie tylko zwracają uwagę na bieżące problemy społeczne, lecz również dociekają ich genezy i źródeł. Co więcej, Usowicz dzieli się z czytelnikiem tezą, iż renesansowego myśliciela można postawić obok wielkich moralistów społecznych naszego narodu, w tym obok samego ks. Piotra Skargi, który zresztą miał wysoko cenić Sokołowskiego. Jasny i klarowny układ tekstu, a przede wszystkim pogłębiona analiza poglądów bądź co bądź mało znanej postaci z dziejów polskiej filozofii - sprawiają,

\footnotetext{
A. Usowicz, Poglądy moralno-polityczne ks. Stanisława Sokołowskiego, „Nasza Przeszłość” 1 (1946), s. 97-126. Program ideowy czasopisma, wyrażony w pierwszym numerze periodyku, doskonale korespondował z charakterem rozprawy ks. Usowicza: „Wszystko zatem, co tylko ma związek z historią kultury katolickiej w Polsce, stanie się przedmiotem zainteresowań naszych i badań. Będziemy zamieszczać rozprawy z dziedziny historii Kościoła w Polsce, historii zakonów, historii teologii, dziejów pracy misyjnej w kraju naszym i za granicą; rozprawy ogólniejszej natury, teologiczne i filozoficzne, historyczno-prawne, społeczne związane z kulturą polską, znajdą również miejsce na łamach naszego wydawnictwa”.
} 
że tekst Usowicza można śmiało zaliczyć do istotnych z punktu widzenia opracowań historyczno-krytycznych.

Kilkanaście miesięcy po ukazaniu się artykułu o Sokołowskim, na łamach „Naszej Przeszłości” ponownie gościł Usowicz, tym razem z pracą zatytułowaną Stanisław Wieczorkowski. Z dziejów Uniwersytetu Jagiellońskiego $w$ pierwszej połowie $x$ VII wieku' Tematyka rozprawy znów nawiązuje tematycznie do dziejów filozofii polskiej, po raz kolejny także pojawia się postać związana ze środowiskiem krakowskim. Jako filozof i teolog, ks. Wieczorkowski - w interpretacji Usowicza - okazuje się postacią charakterystyczną dla ówczesnej kultury i środowiska Akademii Krakowskiej. Na przykładzie ks. Wieczorkowskiego ukazana zostaje zatem specyfika XVII-wiecznego życia naukowego stolicy Polski. Układ tekstu Usowicza o Wieczorkowskim zdradza specyfikę jego pracy jako historyka. Najpierw referuje biografię naukową myśliciela, a następnie omawia pokrótce jego dorobek naukowy, w tym zachowane rękopisy z wykładów do Fizyki Arystotelesa. Ukazując czytelnikowi postać Wieczorkowskiego, wskazuje Usowicz na jego osiągnięcia w dziedzinie gramatyki, retoryki i logiki - uprawianych w duchu arystotelesowskim oraz w nawiązaniu do prac Tomasza Lynacre’a i Adama Romera ze Stężycy - a także psychologii racjonalnej, filozofii prawa i filozofii przyrody, opartej na dorobku takich myślicieli, jak Arystoteles, Albert Wielki, św. Tomasz z Akwinu czy Jacques Charpentier. Oceniając działalność Wieczorkowskiego, Usowicz stawia tezę, że jego praca pedagogiczna była typowa dla ówczesnego środowiska krakowskiego, w którym podejmowano głębokie zagadnienia, pozostające jednak objawem wspólnego dziedzictwa scholastyków. Usowicz z szacunkiem podchodzi do tego dorobku, pisząc, że „trzeba uszanować te prace, jako wyraz gromadzenia prawdy kropla po kropli trudem wielu pokoleń”, choć - jak zauważa z nutą wyczuwalnego dystansu - „nie można w całości ich naśladować, bo trzeba stare rzeczy wiązać z nowymi”".

Kolejny wkład Usowicza w badania nad krakowską tradycją scholastyczną wiąże się z artykułem opublikowanym w 1948 roku, ponownie na łamach „Naszej Przeszłości”, zatytułowanym Traktaty Jana z Głogowa jako wyraz

A. Usowicz, Stanisław Wieczorkowski. Z dziejów Uniwersytetu Jagiellońskiego w pierwszej połowie XVII wieku, „Nasza Przeszłość” 3 (1947), s. 145-161.

A. Usowicz, Stanisław Wieczorkowski..., s. 161. 
kultury średniowiecznej ${ }^{9}$. Warto zaznaczyć, iż dorobek Jana z Głogowa, znaczącego przedstawiciela krakowskiego tomizmu przełomu XV i XVI wieku, był już wcześniej poddany analizie przez historyków filozofii, m.in. Michalskiego. Usowicz w swoim własnym artykule podejmuje refleksję nad spuścizną Głogowczyka w kontekście działalności środowiska krakowskiego, które w ówczesnym czasie - nie bez trudu i pewnych opóźnień - intensywnie zabiegało o recepcję europejskiej myśli średniowiecza. W artykule Usowicz tradycyjnie już omawia pokrótce wątki z biografii analizowanego autora oraz przedstawia jego traktaty drukowane i rękopiśmienne, dzieląc je na kilka grup tematycznych (traktaty gramatyczne, logiczne, z zakresu filozofii przyrody, metafizyczne, astrologiczno-astronomiczne i geograficzne). Usowicz zwraca także uwagę na pozytywną ocenę, jaką Głogowczyk nadaje filozoficznej tradycji, z której namiętnie czerpie, nawiązując nie tylko do św. Tomasza z Akwinu czy Alberta Wielkiego, ale także Pawła z Wenecji, Jana z Jandun, Egidiusza Rzymskiego, Awicenny, Porfiriusza, Seneki i innych. Usowicz dostrzega, że Jan z Głogowa to typ filozofa, który potrafi wzbogacić badania kompilatorskie i objaśnienia historyczne o własny, autorski komentarz. Dużą część artykułu Usowicza stanowi prezentacja poglądów Głogowczyka na gramatykę, logikę, filozofię przyrody i psychologię racjonalną. Istotna teza, wieńcząca pracę, dotyczy stosunku myśli średniowiecza do nowożytności. Usowicz odważnie jak na swoje czasy stwierdza, iż humanizm czasów nowożytnych postał nie wbrew kulturze średniowiecza, lecz na jej gruncie. Mimo że odrodzenie krytykowało idee poprzedniej epoki, samo namiętnie z nich czerpało. Jan z Głogowa, dzięki rozległości swoich zainteresowań, miał według Usowicza kłaść podstawy ideowe pod renesans - zwłaszcza na ziemiach polskich, gdzie na przełomie XV i XVI wieku wciąż panowała kultura średniowiecza, choć dochodziły już do głosu idee kultury antycznej.

Powyższe tezy wybrzmiały również w krótkim tekście Usowicza, zatytułowanym Nowożytne elementy w średniowiecznych traktatach politycznych ${ }^{10}$. Ksiądz Usowicz uważał, że idee nowożytnej filozofii społecznej, jak choćby problem ograniczenia władzy państwowej czy wpływ czynników geograficznych na życie w państwie, obecne były już w pismach średniowiecznych

9 A. Usowicz, Traktaty Jana z Głogowa jako wyraz kultury średniowiecznej, „Nasza Przeszłość" 4 (1948), s. 125-156.

${ }^{10}$ A. Usowicz, Nowożytne elementy $w$ średniowiecznych traktatach politycznych, „Polonia Sacra" $1948 \mathrm{nr}$ 1, s. 310-311. 
autorów, m.in. u św. Tomasza z Akwinu i Hieronima Savonaroli. Co więcej, poglądy zawarte w średniowiecznych traktatach politycznych silne oddziaływały nie tylko na Zachodzie, ale także w środowisku krakowskim. Niewątpliwie ten aspekt pracy Usowicza, związany z powyższymi uwagami, ujawnia jego żywe zainteresowania dziejami filozoficznymi środowiska, w którym samemu przyszło mu pracować.

Kolejne dwa artykuły Usowicza, pochodzące z lat 1948-1949, dotyczą filozofów związanych ze środowiskiem Uniwersytetu Jagiellońskiego z przełomu XIX i Xx wieku. Tekst o ks. Franciszku Gabrylu (1866-1914) to właściwie rozbudowana nota biograficzna, umieszczona w siódmym tomie Polskiego słownika biograficznego ${ }^{11}$. W swoim tekście Usowicz, oprócz wątków stricte biograficznych, zwraca także uwagę na zainteresowania naukowe filozofa i teologa krakowskiego (związanego również m.in. ze środowiskiem tomistów lowańskich), a następnie rektora Uniwersytetu Jagiellońskiego. Usowicz dostrzega przy tym, iż Gabryl oddziaływał z jednej strony jako historyk polskiej filozofii, z drugiej zaś jako filozof-systematyk, który z powodzeniem wprowadzał odrodzoną scholastykę w rodzime środowisko intelektualne. Według Usowicza ogrom zainteresowań Gabryla, obejmujących także współczesną filozofię, przyczynił się do tego, iż nie mógł on ostatecznie rozwinąć własnych, oryginalnych i twórczych dzieł.

Odmienny charakter miało opracowanie poświęcone o. Jackowi Woronieckiemu (1878-1949), które ukazało się na łamach „Przeglądu Powszechnego" tuż po śmierci krakowskiego dominikanina ${ }^{12}$. W artykule Usowicz kreśli sylwetkę wielkiego uczonego, który w trakcie swojego życia dał się poznać nie tylko jako filozof, ale także jako działacz społeczno-religijny. Usowicz zwraca uwagę na bogatą ścieżkę naukową o. Woronieckiego (m.in. współpraca z Komisją Historii Filozofii na Akademii Umiejętności, praca naukowa na Katolickim Uniwersytecie Lubelskim), szeroki zakres jego zainteresowań (np. etyka, pedagogika, ascetyka, hagiografia), zaufanie do „żywego słowa” (wzorzec nauczania średniowiecznego, wywodzącego się zwłaszcza z tradycji francuskiej) oraz - co wydaje się rzeczą oczywistą - umiłowanie filozofii tomistycznej. Usowicz stwierdza wręcz, że prace o. Woronieckiego są „opromienione myślą tomistyczną", która według dominikanina opiera się na kilku

11 A. Usowicz, Gabryl Franciszek (1866-1914), w: Polski słownik biograficzny, t. 7, Kraków 1948, s. 193-194.

12 A. Usowicz, O. Jacek Woroniecki, „Przegląd Powszechny” 228 (1949), s. 121-133. 
fundamentach: 1) praca filozoficzna jest funkcją społeczną, a obowiązkiem każdego filozofa jest poznać wyniki, do jakich doszła przed nim myśl ludzka (tomizm jako filozofia nawiązująca do tradycji), 2) przedmiotem rozumu jest sam byt (tomizm jako filozofia realistyczna), 3) praca filozoficzna ma związek z życiem moralnym (tomizm jako filozofia podporządkowana celowi obiektywnemu, odnoszącemu się do wszystkich czasów i ludzi). Zwracając uwagę na żywy oddźwięk wielu powiązanych ze sobą idei, jakie w swojej działalności poruszał o. Woroniecki, Usowicz stwierdza ostatecznie, iż wkład dominikanina w polską kulturę katolicką ocenić należy pozytywnie.

Artykuł poświęcony o. Woronieckiemu jest ostatnią samodzielną pracą, poświęconą postaci znaczącej dla tradycji scholastycznej w Krakowie, nie wliczając w to rzecz jasna dorobku Usowicza o swoim mistrzu, ks. Michalskim. Dla dopełnienia obrazu całości należy jeszcze wspomnieć w tym miejscu o krótkiej notce biograficznej na temat dawnego rektora Akademii Krakowskiej, Grzegorza ze Stawiszyna (1481-1540), jaką Usowicz sporządził wraz z Hajdukiewiczem do 9 tomu Polskiego słownika biograficznego ${ }^{13}$. Grzegorz ze Stawiszyna jest w owym tekście przedstawiony jako interpretator Arystotelesa w duchu Jacquesa’a Lefevre'a, propagator terminizmu, myśliciel hołdujący eklektyzmowi tomistyczno-skotystycznemu.

Pojedyncze prace Usowicza podejmujące tematykę dziejów scholastyki krakowskiej skupiają się przede wszystkim na okresie od xv do XviI wieku, a także na uwspółcześnionym tomizmie nurtu lowiańskiego, obecnym w Krakowie na przełomie xix i xx wieku. W celu zaprezentowania tradycji scholastycznych obecnych w środowisku krakowskim Usowicz wybrał metodę analizy dorobku filozoficznego wybranych, można by powiedzieć "modelowych” postaci, specyficznych dla danego okresu historycznego. Styl pracy krakowskiego uczonego jest przy tym bardzo drobiazgowy, osadzony w licznych materiałach źródłowych. Usowicz wykazuje się także dużą biegłością w zakresie historii filozofii powszechnej, dokumentując przenikanie refleksji filozoficznej Zachodu na ziemie polskie. Stawiając tezę o obecności średniowiecznych idei w czasach nowożytnych i ich oddziaływaniu na odrodzenie, niewątpliwie mógł budzić sprzeciw tych filozofów, którzy na wzór Hegla odrzucali dorobek dziesięciu wieków historii myśli europejskiej jako niewiele znaczący. Z drugiej strony można było dostrzec również swego

13 A. Usowicz, L. Hajdukiewicz, Grzegorz ze Stawiszyna, w: Polski słownik biograficzny, t. 9, Kraków 1960, s. 89-90. 
rodzaju dystans Usowicza do myśli średniowiecza, widoczny chociażby w zakończeniu rozprawy o Wieczorkowskim. Być może świadczy to o tym, że w myśli Usowicza szczególnie doniosłą rolę odgrywał duch filozofii tomistycznej - otwartej także na to, co „nowe”.

\section{Systematyczne badania nad spuścizną naukową ks. Konstantego Michalskiego}

Znaczące miejsce $\mathrm{w}$ dorobku naukowym Usowicza zajmują prace poświęcone jego nauczycielowi, ks. Michalskiemu, wybitnemu tomiście wywodzącemu się ze szkoły lowańskiej, który zasłynął przede wszystkim z osiągnięć na gruncie historii filozofii średniowiecza ${ }^{14}$. Doskonale rozumiejąc wkład swojego nauczyciela w badania nad myślą scholastyczną, Usowicz nie szczędził czasu na publikowanie opracowań poświęconych znanemu mediewiście. Świadczy o tym chociażby książka napisana wspólnie z ks. Kazimierzem Kłósakiem, zatytułowana po prostu Ksiądz Konstanty Michalski (1879-1947) i opublikowana $\mathrm{w} 1949 \mathrm{roku}^{15}$. To systematyczne studium historyczno-analityczne spuścizny ks. Michalskiego nie było jednak ani pierwszym, ani ostatnim wkładem Usowicza w rozwój badań nad dorobkiem naukowym swojego nauczyciela. W latach 1947-1948 publikuje już kilka wspomnień pośmiertnych o swoim mistrzu na łamach tygodnika „Niedziela”, czasopisma „Homo Dei” oraz „Przeglądu Filozoficznego”"16. W kolejnych latach wielokrotnie będzie inicjował wydawanie dzieł ks. Michalskiego - m.in. w ramach serii Studia do Dziejów Wydziału Teologicznego Uniwersytetu Jagiellońskiego w Krakowie - nierzadko dokładając przy tym autorski

\footnotetext{
${ }^{14}$ Roman Ingarden pisał w 1947 roku o Michalskim, że „był najwybitniejszym, jak dotąd, polskim historykiem filozofii, a zarazem pierwszym w Polsce uczonym, który badania w zakresie historii filozofii postawił na prawdziwie europejskim poziomie, sięgając wprost do źródeł i prowadząc studia samodzielnie na odcinkach przed nim mało zbadanych lub zgoła nieznanych. Był zarazem pierwszym uczonym polskim, który pracując nad wyjaśnieniem głównych prądów w filozofii późnego średniowiecza na terenie Francji i Anglii w wieku XIV, wniósł w tej dziedzinie trwały i istotny dorobek w naukę europejską" (R. Ingarden, Ks. Konstanty Michalski. Uczony - filozof - człowiek, „Tygodnik Powszechny” 1947 nr 34, s. 1).

${ }^{15}$ A. Usowicz, K. Kłósak, Ksiądz Konstanty Michalski (1879-1947), Kraków 1949.

${ }^{16}$ A. Usowicz, Ksiądz Konstanty Michalski, „Niedziela” 1947 nr 34, s. 274; A. Usowicz, Ksiądz Konstanty Michalski, „Homo Dei” 1947 nr 16, s. 415-419; A. Usowicz, Ksiądz Konstanty Michalski, „Przegląd Filozoficzny” 1948 nr 1, s. 348-356.
} 
komentarz ${ }^{17}$. Usowicz opublikuje także kilka oryginalnych artykułów analitycznych oraz wspomnień ${ }^{18}$. Szczegółowej analizie podda korespondencję między Janem Łukaszewiczem a ks. Michalskim ${ }^{19}$. W 1987 roku odnajdzie fragment rozprawy habilitacyjnej swojego nauczyciela, który opublikuje wraz z komentarzem na łamach czasopisma „Analecta Cracoviensia” ${ }^{20}$ (inna część rozprawy ukaże się w jednym z numerów „Studiów Mediewistycznych" ${ }^{21}$ ). Ponadto wspólnie z wykładowcą Papieskiej Akademii Teologicznej - ks. Wojciechem Paluchowskim - opracuje również czterostronicową notę biograficzną ks. Michalskiego na rzecz publikacji Słownik biograficzny katolickiego duchowieństwa śląskiego XIX $i$ XX wieku ${ }^{22}$. Jak widać, rozpiętość czasowa i tematyczna publikowanych prac o ks. Michalskim jest bardzo szeroka. Wśród tych kilkunastu materiałów znajdują się również obszerniejsze rozprawy, które w bardzo przystępny sposób naświetlają sylwetkę i poglądy filozoficzne wybitnego krakowskiego mediewisty, stanowiąc tym samym cenne źródło dla badaczy, pragnących zajmować się analizą dorobku naukowego Michalskiego.

17 A. Usowicz, Przedmowa, w: K. Michalski, Między heroizmem a bestialstwem, Kraków 1949, s. 5-8; A. Usowicz, Słowo wstępne, „Polonia Sacra” 3 (1950), s. 201-202; A. Usowicz, R. Ingarden, Avant-propos, w: K. Michalski, La gnoseologie de Dante, Kraków 1950; A. Usowicz, Wstęp i wybór tekstów, w: K. Michalski, Nova et vetera, Kraków 1979; A. Usowicz, J. Dukała, Wstęp, w: K. Michalski, Spotkanie z prawda, Kraków 1982; A. Usowicz, O autorze książki, w: K. Michalski, Między heroizmem a bestialstwem, s. 3-23; A. Usowicz, Wprowadzenie do artykułu ks. K. Michalskiego „Problem powszedników w ujęciu psychologicznym u Jana Burydana”, „Analecta Cracoviensia” 20 (1988), s. 51; A. Usowicz, Arte et ratione, w: K. Michalski, Dilatato corde, Kraków 2002, s. 606-620.

18 A. Usowicz, Deum et animam scire cupio, „Polonia Sacra” 3 (1950), s. 203-208; A. Usowicz, Sapientia Christiana, „Śląskie Studia Historyczno-Teologiczne” 2 (1969), s. 9-18; A. Usowicz, Ksiądz Konstanty Michalski (1879-1947), w: W nurcie zagadnień posoborowych, red. B. Bejze, t. 4, Kraków 1979, s. 341-367; A. Usowicz, Idee przewodnie w filozofii ks. Konstantego Michalskiego, w: P. Ricoeur, Filozofia osoby, tłum. M. Frankiewicz, Kraków 1992, s. 7-13.

${ }_{19}$ A. Usowicz, Listy Jana Łukasiewicza do ks. Konstantego Michalskiego, „Analecta Cracoviensia [studia philosophico-theologica edita a professoribus Cracoviae]” 1 (1969), s. 466-477.

${ }^{20}$ A. Usowicz, Wprowadzenie do artykułu ks. K. Michalskiego „Problem powszedników w ujęciu psychologicznym u Jana Burydana”..., s. 51.

${ }^{21}$ K. Michalski, Poglądy etyczne Jana Burydana, "Studia Mediewistyczne” 26 (1989) nr 1, S. $25-83$.

${ }^{22}$ A. Usowicz, W. Paluchowski, Michalski Konstanty Józef, w: Słownik biograficzny katolickiego duchowieństwa śląskiego XIX i XX wieku, red. M. Patera, Katowice 1996, s. 272-275. 
Warto zadać pytanie, w jaki sposób „odczytywał” myśl swojego nauczyciela Usowicz. Jeśli chodzi o punkt wyjścia, to zdecydowanie postrzegał filozofię Michalskiego w kontekście tradycji arystotelesowsko-tomistycznej. Co ciekawe, zwracał przy tym uwagę, że miał on w sobie coś $\mathrm{z}$ augustynika wieków średnich, który potrafi dostrzec ożywczą komunikację między refleksją teologiczną a filozoficzną, pomimo istniejących między nimi granic metodologicznych ${ }^{23}$. Z drugiej strony Usowicz podkreślał, że „dla niego (tj. ks. Michalskiego) nie istniał konflikt starego z nowym" ${ }^{24}$. Oprócz doskonałej znajomości tradycyjnej filozofii uprawianej w duchu chrześcijańskim, Michalski miał dobrze orientować się we współczesnych mu nurtach filozoficznych. Przyjęta przez niego metoda filozofowania ostatecznie pozostała jednak bliższa ideałom wieków średnich. Jak pisał Usowicz, „średniowiecze, na którym wzorował się ks. Michalski, umiało rozwijać swe poglądy nie tylko $\mathrm{w}$ formie suchych komentarzy do Piotra Lombarda; umiało je również podawać w miłej formie dialogu, modlitwy zwróconej do Boga, w formie wiersza czy swobodnego wykładu, nieskrępowanego sylogizmem. Ks. Michalski i w tym względzie szedł drogami średniowiecza. Filozofię swą bowiem zawarł nie tylko w dziełach ściśle naukowych; zawarł ją również w artykułach naukowo-popularnych" ${ }^{25}$. W innym miejscu Usowicz napisze, że Michalski miał w sobie coś z ducha Platońskiego Fajdrosa, który cenił pismo, choć kochał żywe słowo ${ }^{26}$. W związku $\mathrm{z}$ tym recepcja jego myśli nie powinna odbywać się w oderwaniu od analizy mniej sformalizowanych tekstów, jak notatki, zapiski z podręczników, korespondencje $\mathrm{e}^{27}$. Postawa badawcza Usowicza świadczy tutaj o ogromnym szacunku do niepublikowanych źródeł historycznych. Zastosowana metoda zdradza także zamiłowanie Usowicza do wszechstronnych, kompleksowych ujęć, koncentrujących się na uchwyceniu możliwie najbardziej wiernego obrazu sylwetki ks. Michalskiego jako uczonego.

Przeprowadzając badania nad spuścizną naukową swojego nauczyciela, Usowicz skupił się na wyodrębnieniu w jego dorobku głównych idei, wokół których krążyła myśl autora Między heroizmem a bestialstwem. Dostrzegalne

${ }^{3}$ A. Usowicz, Sapientia Christiana..., s. 10.

${ }^{24}$ A. Usowicz, Deum et animam scire cupio..., s. 208.

${ }_{25}$ A. Usowicz, Życie i dzieła ks. Konstantego Michalskiego, w: A. Usowicz, K. Kłósak, Ksiądz Konstanty Michalski (1879-1947), Kraków 1949, s. 109.

${ }^{26}$ A. Usowicz, Życie i dzieła ks. Konstantego Michalskiego, s. 7.

${ }^{27}$ A. Usowicz, O autorze książki..., s. 4. 
jest to chociażby przy podziale prac mediewistycznych ks. Michalskiego na trzy grupy. Usowicz wyodrębnił w dorobku swojego nauczyciela teksty mediewistyczne z zakresu: 1) polskiej myśli scholastycznej, 2) filozofii zachodniej XIV wieku, 3) myśli Dantego (tzw. dantologia). Zwracał przy tym uwagę, że Michalski w swoich opracowaniach historycznych uwzględniał nie tyle gotowe systemy, ile problemy; zagadnienia aktualne miały natomiast stanowić inspirację do poszukiwania podobnych idei w myśli późnośredniowiecznej $^{28}$. Obszar tematyczny prac mediewistycznych ks. Michalskiego był bardzo szeroki, obejmował bowiem teksty historyczne dotyczące m.in. logiki, epistemologii, etyki, filozofii przyrody.

Rozległość zainteresowań Michalskiego ujawnia się także w pracach stricte problemowych. Usowicz w swoich analizach zwraca uwagę na teocentryczny charakter filozofii swojego nauczyciela. To Bóg, a nie człowiek ma być ostatecznym odniesieniem podejmowanych analiz, choć problematyka antropologiczna nadal pełni w rozważaniach doniosłą rolę. W związku z tym ks. Michalski chętnie polemizował z nowszymi ideami związanymi z tematyką dotyczącą człowieka. Tym sposobem dyskutował np. z ideą atomizmu w psychologii, skłaniając się samemu do organicznego myślenia o człowieku i otaczającej nas rzeczywistości, co miało stanowić jeden z przejawów jego tomistycznych zapatrywań. Konsekwencją tego podejścia miała być także specyficzna historiozofia, koncentrująca się wokół idei rozwoju (perfekcjoryzm) ku coraz wyższym stanom. Rozwój ku etapom bardziej doskonałym ma prowadzić w przypadku człowieka do kontaktu jego duszy z Bogiem, który oddziałuje na jednostkę jako mądry wychowawca. Bóg ten jest $\mathrm{z}$ jednej strony immanentny (obecny w przyrodzie, człowieku i grupach społecznych), a zarazem transcendentny ${ }^{29}$. Omawiając powyższe poglądy Michalskiego, Usowicz zwraca uwagę na ich zakorzenienie w myśli św. Tomasza, a zarazem oryginalny charakter i twórcze nawiązywanie do problemów współczesności (m.in. polemika z pozytywizującym ujęciem rzeczywistości, modernizmem, deizmem). Usowicz zwraca zresztą uwagę na zainteresowania Michalskiego nowożytną nauką, chociażby zagadnieniami współczesnej mu psychologii empirycznej, którą bardzo cenił - zwłaszcza jej metodę statystyczną i osiągnięcia na gruncie fizjologii (Wilhelm Wundt). Z drugiej strony Usowicz podkreśla, że Michalski nie pochwalał jej rozbratu z filozofią.

\footnotetext{
${ }^{28}$ A. Usowicz, W. Paluchowski, Michalski Konstanty Józef..., s. 273.

${ }_{29}$ A. Usowicz, Deum et animam scire cupio..., s. 203-204.
} 
Zgodnie z przyjętą metodą bazowania na bezpośrednich źródłach Usowicz przybliża w swoich tekstach sylwetkę Michalskiego także w kontekście prowadzonych przez „mistrza” korespondencji. Wydaje się to niewątpliwie słuszne, gdyż lista uczonych, którzy pisywali na tematy naukowe do polskiego mediewisty jest bardzo szeroka i obejmuje nazwiska znaczących filozofów. Wśród nich znajdują się m.in. Étienne Gilson, Reginald Garrigou-Lagrange czy, ze strony polskiej, fenomenolog Roman Ingarden i przedstawiciel szkoły lwowsko-warszawskiej, Jan Łukaszewicz, którego korespondencję do Michalskiego poddał Usowicz bardzo drobiazgowej analizie ${ }^{30}$.

Z powyższego przeglądu wyłania się obraz Usowicza jako znawcy i badacza spuścizny Michalskiego. Usowicz zajmuje się nie tylko kompilacją dzieł swojego mistrza czy ewentualnymi pracami edytorskimi, ale także twórczą recepcją i analizą jego poglądów w kontekście przyjmowanych źródeł, metody i charakteru uprawianej filozofii. Wkład Usowicza do badań nad spuścizną Michalskiego wydaje się w tym kontekście nieoceniony i zasługuje na odnotowanie w pracach historyczno-krytycznych.

\section{Zakończenie}

W artykule podjęto próbę uzasadnienia tezy o wkładzie Usowicza do badań nad krakowską filozofią. Wydaje się, że w świetle zaprezentowanego materiału badawczego Usowicza, obejmującego prace z zakresu rodzimej myśli filozoficznej, udało się uwiarygodnić wysuniętą tezę. Oczywiście w tym miejscu mogą powstać zasadne pytania o kryteria, jakimi kierowano się przy uzasadnianiu przyjętego stanowiska, a także dotyczące rozumienia tytułowego „wkładu” Usowicza w badania nad krakowską filozofią. Autor niniejszego opracowania założył (być może oszczędnie?), że prace dotyczące filozofii krakowskiej są w przypadku Usowicza wystarczająco liczne, tematycznie szerokie i twórcze pod względem naukowym, że warto poświęcić im uwagę. Usowicz jawi się bowiem niewątpliwie jako jeden z pionierów powojennej historii filozofii polskiej, publikując w latach 1946-1949 kilka znaczących artykułów dotyczących myśli filozoficznej środowiska krakowskiego z wieków XV-XVII i XIX-Xx, obrazujących ideowy klimat tych właśnie okresów historycznych. Ponadto Usowicz zasługuje na miano czołowego komentatora myśli Konstantego Michalskiego, niewątpliwie jednego z najważniejszych

\footnotetext{
${ }^{30}$ A. Usowicz, Listy Jana Łukasiewicza..., s. 118-129.
} 
krakowskich myślicieli katolickich pierwszej połowy xx wieku. W związku z tym nie musi dziwić teza, w myśl której uznaje się Usowicza za ważnego przedstawiciela historii filozofii polskiej.

W celu oddania jego zasług warto przywołać także słowa Jana Pawła II, który w telegramie na wieść o śmierci Usowicza pisał o nim, że „był znakomitym naukowcem i pedagogiem, cenionym nie tylko w środowisku krakowskim, ale także w całej Polsce i na świecie. Kraków jednak zawdzięcza mu najwięcej" ${ }^{31}$. Usowicz, związany przez całe lata z Papieską Akademią Teologiczną, sam zresztą współtworzył środowisko filozofów krakowskich. Rzecz godna uwagi - pomimo głębokiego przywiązania do tomizmu, pozostawał otwarty m.in. na prowadzone na PAT badania z zakresu filozofii przyrody (opierającej się, jak sam zauważał, na wszechstronnej znajomości nauk szczegółowych), wyrażał także duże zaufanie do metody fenomenologicznej - specyficznej dla ks. Tischnera i jego uczniów - którą uważał za pożyteczną dla rozwiązywania wielkich problemów filozofii tradycyjnej ${ }^{32}$. Wielkość środowiska Papieskiej Akademii Teologicznej podkreślił także w związku ze swoim przejściem na emeryturę, gdy podczas obrad Rady Wydziału dziękował współpracownikom za ich „postawę autentycznie humanistyczną"33.

\section{Bibliografia}

Ingarden R., Ks. Konstanty Michalski. Uczony - filozof - człowiek, „Tygodnik Powszechny"1947 nr 34, s. 1-2.

Markowski M., Aleksander Usowicz - wielki uczony i dobry nauczyciel przełomowych czasów, „Informator Instytutu Teologicznego Księży Misjonarzy” 2002 nr 22, s. 25-77.

Michalski K., Między heroizmem a bestialstwem, Częstochowa 1984.

Michalski K., Poglądy etyczne Jana Burydana, „Studia Mediewistyczne” 26 (1989) nr 1, s. 25-83.

Pawlikowski T., Filozofia teoretyczna ks. Aleksandra Usowicza, Kraków 2009.

${ }^{31}$ Telegram Jana Pawła II z 11 czerwca 2002 r. przysłany po śmierci ks. prof. Aleksandra Usowicza do J.E. kard. F. Macharskiego Arcybiskupa Metropolity Krakowskiego, „Informator Instytutu Teologicznego Księży Misjonarzy” 2002-2003 nr 22, s. 7-8.

${ }_{32}$ Zob. A. Usowicz, Filozofia - teologia - historia, „Tygodnik Powszechny” 1983 nr 3, s. 7-8.

33 „Biuletyn Papieskiej Akademii Teologicznej w Krakowie” 1990/1991 nr 9, s. 182. 
Podziękowanie dla Ks. Prof. Aleksandra Usowicza, „Biuletyn Papieskiej Akademii Teologicznej w Krakowie” 1990/1991 nr 9, s. 182.

Skoczyński J., Woleński J., Historia filozofii polskiej, Kraków 2010.

Telegram Jana Pawła II z 11 czerwca 2002 r. przysłany po śmierci ks. prof. Aleksandra Usowicza do J.E. kard. F. Macharskiego Arcybiskupa Metropolity Krakowskiego, „Informator Instytutu Teologicznego Księży Misjonarzy” 2002-2003 nr 22, s. 7-8. Usowicz A., Arte et ratione, w: K. Michalski, Dilatato corde, Kraków 2002, s. 606-62o. Usowicz A., Deum et animam scire cupio, „Polonia Sacra” 3 (1950), s. 203-208.

Usowicz A., Filozofia - teologia - historia, „Tygodnik Powszechny” 1983 nr 3, s. 7-8. Usowicz A., Gabryl Franciszek (1866-1914), w: Polski słownik biograficzny, t. 7, red.

W. Konopczyński, Kraków 1948, s. 193-194.

Usowicz A., Idee przewodnie w filozofii ks. Konstantego Michalskiego, w: P. Ricoeur, Filozofia osoby, tłum. M. Frankiewicz, Kraków 1992, s. 7-13.

Usowicz A., J. Dukała, Wstęp, w: K. Michalski, Spotkanie z prawda, Kraków 1982, s. 5- 7. Usowicz A., K. Kłósak, Ksiądz Konstanty Michalski (1879-1947), Kraków 1949.

Usowicz A., Ksiądz Konstanty Michalski (1879-1947), w: W nurcie zagadnień posoborowych, red. B. Bejze, t. 4, Kraków 1979, s. 341-367.

Usowicz A., Ksiądz Konstanty Michalski, „Homo Dei” 1947 nr 16, s. 415-419.

Usowicz A., Ksiądz Konstanty Michalski, „Niedziela” 1947 nr 34, s. 274.

Usowicz A., Ksiądz Konstanty Michalski, „Przegląd Filozoficzny” 1948 nr 1, s. 348356.

Usowicz A., Hajdukiewicz L., Grzegorz ze Stawiszyna, w: Polski słownik biograficzny, t. 9, red. K. Lepszy, Kraków 1960, s. 89-90.

Usowicz A., Listy Jana Łukasiewicza do ks. Konstantego Michalskiego, „Analecta Cracoviensia" 1 (1969), s. 118-129.

Usowicz A., Nowożytne elementy w średniowiecznych traktatach politycznych, „Polonia Sacra" $1948 \mathrm{nr}$ 1, s. 310-311.

Usowicz A., O. Jacek Woroniecki, „Przegląd Powszechny” 228 (1949), s. 121-133.

Usowicz A., Poglady moralno-polityczne ks. Stanisława Sokołowskiego, „Nasza Przeszłość" 1 (1946), s. 97-126.

Usowicz A., Ingarden R., Avant-propos, w: K. Michalski, La gnoseologie de Dante, Kraków 1950, s. 3-5.

Usowicz A., Sapientia Christiana, „Śląskie Studia Historyczno-Teologiczne” 2 (1969), s. 9-18.

Usowicz A., Słowo wstępne, „Polonia Sacra” 3 (1950), s. 201-202.

Usowicz A., Stanisław Wieczorkowski. Z dziejów Uniwersytetu Jagiellońskiego w pierwszej połowie XVII wieku, „Nasza Przeszłość” 3 (1947), s. 145-161. 
Usowicz A., Traktaty Jana z Głogowa jako wyraz kultury średniowiecznej, „Nasza Przeszłość" 4 (1948), s. 125-156.

Usowicz A., Paluchowski W., Michalski Konstanty Józef, w: Słownik biograficzny katolickiego duchowieństwa śląskiego XIX $i$ XX wieku, red. M. Patera, Katowice 1996, s. 272-275.

Usowicz A., Wprowadzenie do artykułu ks. K. Michalskiego „Problem powszedników w ujęciu psychologicznym u Jana Burydana”, „Analecta Cracoviensia” 20 (1988), s. 51. Usowicz A., Wstęp i wybór tekstów, w: K. Michalski, Nova et vetera, Kraków 1979, s. 173.

Usowicz A., Życie i dzieła ks. Konstantego Michalskiego, w: A. Usowicz, K. Kłósak, Ksiądz Konstanty Michalski (1879-1947), Kraków 1949, s. 5-128.

Wąsik W., Historia filozofii polskiej, t. 1: Scholastyka, renesans, oświecenie, Warszawa 1958.

\section{Streszczenie}

$\mathrm{W}$ artykule podjęto próbę uzasadnienia tezy o wkładzie ks. Aleksandra Usowicza CM w badania nad krakowską filozofią, rozwijaną w dwóch okresach: a) między XV a XVII wiekiem, b) u schyłku XIx i w pierwszej połowie Xx wieku. W świetle przeprowadzonych analiz ks. Usowicz jawi się jako jeden z pionierów powojennej historii filozofii polskiej, publikując w latach 1946-1949 kilka znaczących artykułów dotyczących myśli filozoficznej środowiska krakowskiego z wieków XV-XVII i XIX-Xx. Ponadto ks. Usowicz zasługuje na miano czołowego komentatora myśli Konstantego Michalskiego, niewątpliwie jednego z najważniejszych krakowskich myślicieli katolickich pierwszej połowy $\mathrm{xx}$ wieku.

\section{Słowa kluczowe}

Usowicz, Konstanty Michalski, filozofia polska, neoscholastyka, tomizm

\section{Summary}

\section{Aleksander Usowicz's Contribution to Research on the History of Cracow Philosophy}

The article attempts to justify the thesis that Aleksander Usowicz has made contribution to the research on Cracow philosophy, which was developed in two periods: 
a) between the $15^{\text {th }}$ and $17^{\text {th }}$ centuries, b) at the end of the $19^{\text {th }}$ and the first half of the $2 \mathrm{O}^{\text {th }}$ century. Usowicz was one of the pioneers in post-war history of Polish philosophy, publishing between 1946 and 1949 several important articles, concerning Cracow philosophy (from $15^{\text {th }}$ to $19^{\text {th }}$ centuries). In addition, Usowicz was the leading commentator and interpreter of the philosophical thought of Konstanty Michalski - undoubtedly one of the most important catholic philosophers in the first half of the $20^{\text {th }}$ century.

\section{Keywords}

Usowicz, Konstanty Michalski, Polish philosophy, neo-scholasticism, Thomism 